(C) 2012

Сорокова В. В., кандидат ветеринарних наук

Полтавська державна аграрна академія

\title{
ОСОБЛИВОСТІ ПАТОЛОГО-АНАТОМІЧНОГО ПРОЯВУ ДИРОФІЛЯРІОЗУ СОБАК, СПРИЧИНЕНОГО DIROFILARIA IMMITIS
}

\section{Рецензент - кандидат ветеринарних наук О. В. Кручиненко}

\begin{abstract}
Наведені матеріали стосовно патологоанатомічних змін за дирофіляріозу собак, спричиненого Dirofilaria immitis. Патоморфологічними дослідженнями встановлено кахексію, анемію слизових оболонок, білковий гепатоз, нефрозонефрит, венозну гіперемію та набряк легень, гіпертрофію й гостре розширення правої половини серия, гідроторакс, асцит і гематурію. Показані також зміни, неспецифічні для даного захворювання: катарально-геморагічний гатроентероколіт і геморагічний діатез. У сериі, легенях та легеневих артеріях загиблих від дирофіляріозу собак виявлені статевозрілі паразити Dirofilaria immitis, щฺо призвели до загибелі тварин.
\end{abstract}

Ключові слова: дирофіляріоз, патологоанатомічні зміни, собаки, Dirofilaria immitis, гельмінтоз.

Постановка проблеми. Ріст захворюваності на дирофіляріоз у собак - актуальна проблема ветеринарної медицини в сучасних умовах. Захворювання собак, викликане кардіонематодою Dirofilaria immitis, виявлено в Україні лише кілька років тому. Це нове захворювання має епізоотичне та епідеміологічне значення, тому необхідно вивчати особливості його перебігу в умовах України.

Аналіз основних досліджень і публікацій, у яких започатковано розв'язання проблеми. Дирофіляріоз - захворювання, викликане паразитуванням нематод роду Dirofilaria в організмі м'ясоїдних (собак, кішок, лисиць, вовків, ведмедів). Окремі дослідники вважають, що до дирофіляріозу сприйнятлива і людина $[1,13]$.

Дирофіляріоз реєструється в країнах Африки, Азії та Південної Свропи [8]. У США встановлені ендемічні зони, де щорічно відмічають спалахи цього гельмінтозу [12]. Випадки захворювання зареєстровані у Великобританії, Швеції, Нідерландах, Австрії, Угорщині, Болгарії, Румунії, Німеччині, Польщі, Росії, Казахстані, республіках Північного Кавказу [8]. Нині дирофіляріози спостерігаються в Києві, Одесі, Севастополі, Сімферополі, Харкові, Київській, Чернігівській, Сумській, Полтавській, Харківській та інших областях $[2,4,5,6,8]$.

Що стосується видового складу дирофілярій, то автори часто посилаються на виявлення D. repens, який паразитує в підшкірній клітковині. Інший вид - D. immitis - у серці, легенях, легеневій артерії та інших судинах м'ясоїдних. Іноді ці нематоди паразитують у незвичних місцях (мозок, бронхіоли, черевна порожнина, очі) [14]. Залежно від його локалізації розрізняють внутрішній, або серцевий (D. immitis), та підшкірний (D. repens) дирофіляріози.

Паразитуючи в серці, D. immitis викликає розлади кровообігу в результаті механічної закупорки судин і прогресуючого ендоартеріїту. Захворювання призводить до емболії, тромбозу кровоносних судин, а з часом - до цирозу печінки, асциту і загибелі собак [11].

На розтині трупів загиблих від дирофіляріозу тварин найсуттєвіші зміни знаходять у серці, легеневих судинах і легенях. Відмічають збільшення правого шлуночка серця та артерій правої каудальної частки легені. Збільшується діаметр легеневої артерії. На розрізі краніальної частки легені знаходять дорослих D. immitis, як і в серці [3].

Вплив на інтиму судин характеризується нитковидними розрощеннями, що сягають $6-8 \mathrm{~cm} \mathrm{у}$ довжину і знаходяться у просвіті судин. Вони можуть бути складчастими, папіломатозними (спочатку вони з'являються у передньому кінці легеневої артерії) й гільчастими (у біфуркації великих артерій). Крім того статевозрілі дирофілярії, мертві й такі, що гинуть, викликають тромбози невеликих легеневих артерій, емболію невеликих і великих легеневих артерій [9].

У загиблих собак знаходять набряки (серцевого походження) в ділянці міжщелепового простору, кінцівок, анемію слизових оболонок або, навпаки, ознаки застійної гіперемії (передусім язика та інших органів). Серозно-гнійний кон'юнктивіт, набряки (частіше не симетрично розташовані) окремих ділянок морди виявляють за інтенсивної інвазії.

Нерідко спостерігають асцити, як наслідок порушення роботи серцево-судинної системи, 
рідше - гідроторакс.

У разі зараження собак D. repens, у них виявляють ураження шкіри в ділянках голови та кінцівок у вигляді папульозного дерматиту й множинних виразок [8]. Дорослих гельмінтів знаходять також у підшкірній клітковині, на паренхіматозних органах, передній камері ока та інших ділянках тіла м'ясоїдних. В окремих випадках виявляють у центрі новоутворень пухлинного походження [3].

Більшість переглянутих нами наукових робіт присвячено вивченню екології, епізоотології, розповсюдження, методів лабораторної діагностики D. immitis у собак $[2,4,5,6,10]$. Вивчення клінічних ознак, патогенезу та лікування залишається також актуальним на сьогодні $[7,11]$. Однак питанню вивчення повного комплексу патолого-анатомічних змін дослідники не надають належної уваги.

Мета і завдання досліджень полягали у вивченні особливостей патолого-анатомічного прояву дирофіляріозу у дорослих собак, що спостерігався у Полтавській області.

Матеріали і методи. Дослідження проводили на базі Регіональної державної лабораторії ветеринарної медицини в Полтавській області. Трупи дорослих собак були надіслані до лабораторії 3 м. Полтава та Полтавського району для 3'ясування причин загибелі тварин. Діагноз на дирофіляріоз собак в усіх випадках був підтверджений лабораторними дослідженнями Регіональної державної лабораторії ветеринарної медицини в Полтавській області. Проводилися також бактеріологічні, серологічні та хіміко-токсикологічні дослідження для виключення інших захворювань м'ясоїдних. Анамнез збирали зі слів господарів, а також за даними супровідних документів. Патолого-анатомічні дослідження проводили за класичною методикою. Фотографії робили за допомогою цифрової відеокамери KODAK Z612. Морфологію статевозрілих дирофілярій досліджували за допомогою бінокулярного мікроскопа XSP-139 TP із системою аналізу зображення. Аналіз зображення проводили за допомогою програми «Відео Тест».

Результати дослідження. 3 анамнезу визначили, що за дирофіляріозу у собак перед загибеллю спостерігалися такі клінічні ознаки, як слабкість, пригнічення, підвищена втомлюваність, загальне виснаження, блювота, відмова від корму, судоми та підвищення температури тіла, ознаки патології дихальної й серцево-судинної систем. В однієї з собак клінічні ознаки захворювання виявляли через 5 діб після проведення дегельмінтизації препаратом Drontal Plus. Встановлювали також безсимптомний перебіг дирофіляріозу собак. У більшості випадків прижиттево собакам встановлювали клінічний діагноз отруєння.

Патолого-анатомічними дослідженнями трупів собак встановлювали загальне виснаження (в $80 \%$ випадків), непігментовані видимі слизові оболонки набували світло-сірого забарвлення, що свідчить при анемію (див. табл.).

У грудній порожнині загиблих собак виявляли значну кількість рідини; в одних випадках це була рідина солом'яного кольору (гідроторакс), в інших - кров темно-вишневого кольору (гемоторакс). Плевра - гладка, блискуча, волога.

Легені в усіх випадках були тістуватої консистенції, не збільшені, темно-червоного кольору. На розрізі в разі надавлювання виділялася мутна піниста рідина солом'яного кольору й кров темно-вишневого кольору (венозна гіперемія та набряк легень). За легеневої форми дирофіляріозу собак на розрізі краніальної частки легені та легеневих артерій виявляли значну кількість статевозрілих гельмінтів D. immitis розміром від п'яти до десяти см (у 40 \% досліджених трупів собак). Внутрішня оболонка легеневих артерій нерівна, шорохувата. Як видно із даних таблиці 1, в $40 \%$ випадків спостерігали також реакцію 3 боку лімфовузлів: бронхіальні, середостінні лімфатичні вузли - збільшені, червоного кольору, капсула напружена, фолікули різко виступають.

Серце незначно збільшене, в'ялої консистенціï. Спостерігалося гостре розширення й переповнення кров'ю правої половини серця. Осердя прозоре, сіро-рожевого кольору. Епікард сіророжевого кольору, судини кровонаповнені, на епікарді - плямисті та крапчасті крововиливи. Міокард сіро-рожевого кольору, пружний, ендокард - рожевого кольору. За наявності гельмінтів у серці орган був збільшений, гіпертрофований. В однієї з собак навіть виявлено розриви серцевої стінки в трьох ділянках, краї розривів нерівні, просочені кров'ю (рис. 1). До того жу перикардіальній порожнині виявляли кров червоного кольору (гемоперикардіум). У правому шлуночку серця - значна кількість паразитів D. immitis, довжиною 20-30 см (рис. 2).

У $20 \%$ випадків у черевній порожнині сторонній вміст відсутній. Очеревина волога, гладка, блискуча. В черевній порожнині також виявляли сторонній вміст - скупчення крові темновишневого (гемоперитонеум) або солом'яного кольору (асцит). 


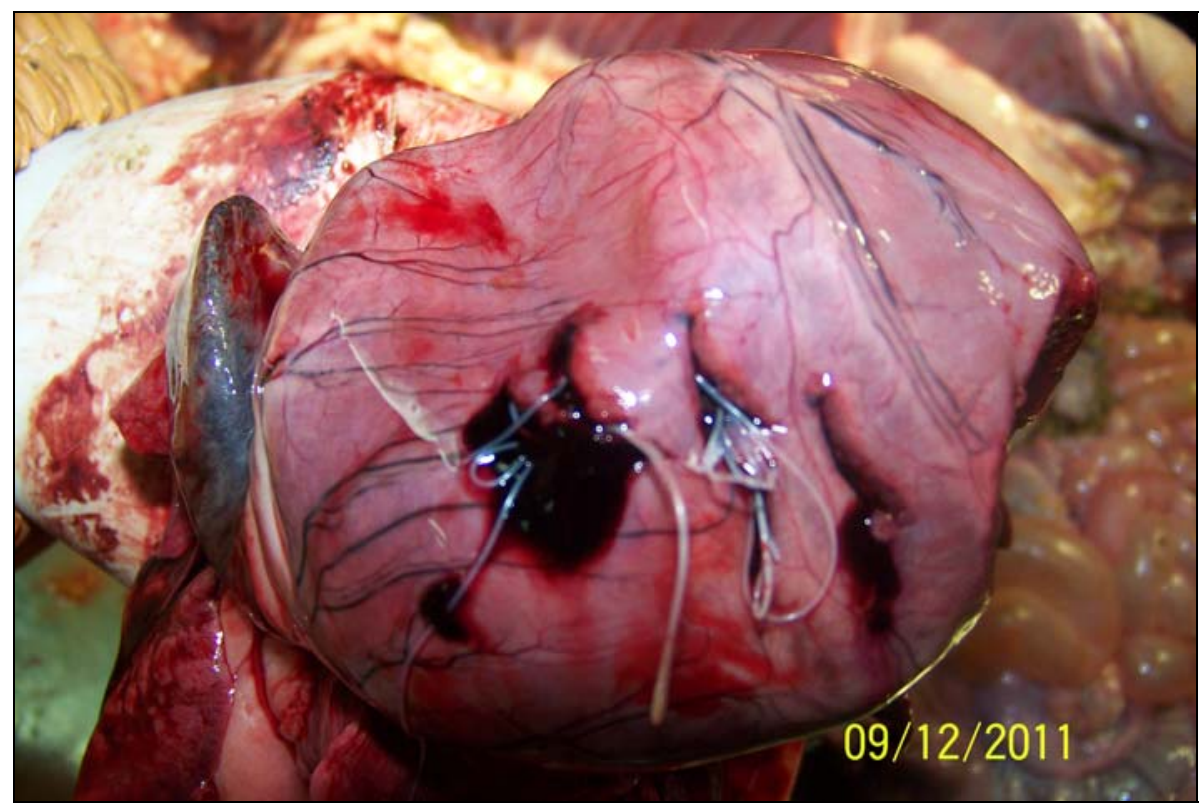

Puc. 1. Статевозрілі D. immitis у серці собаки

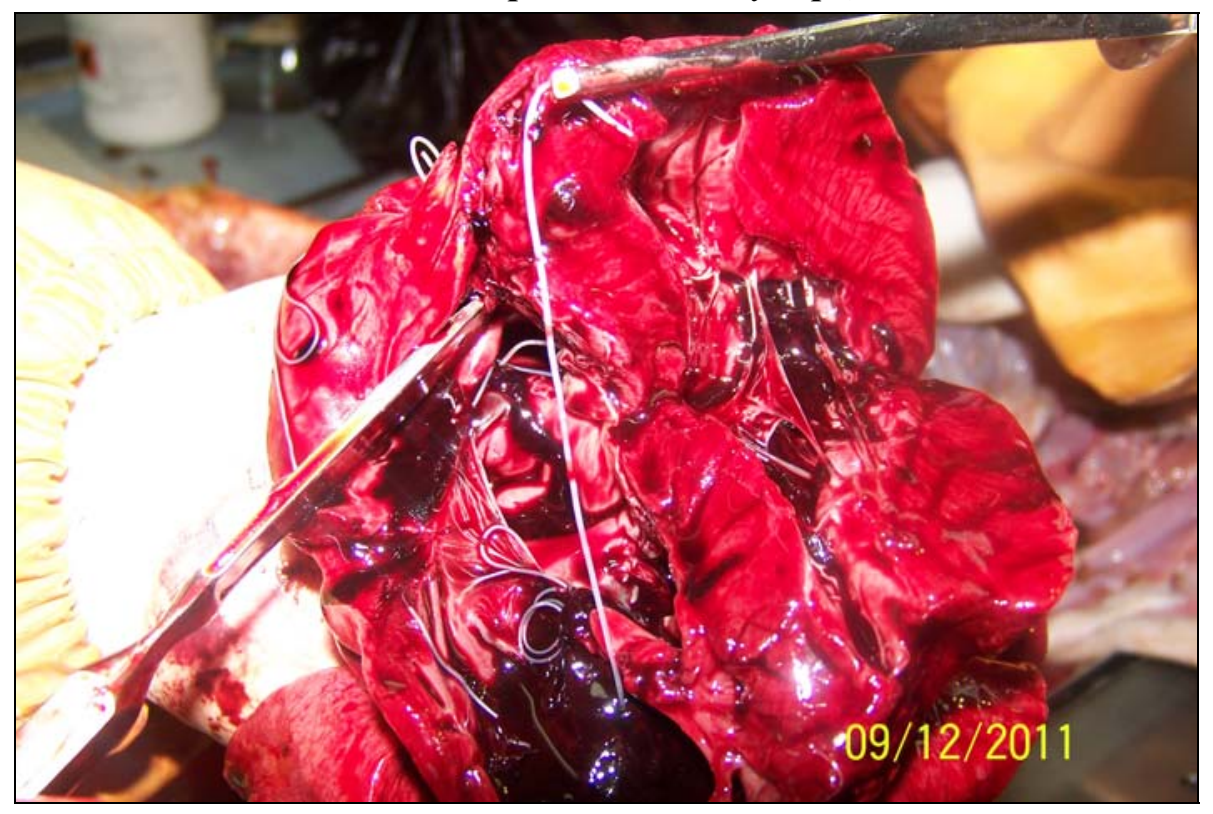

Рис. 2. Дирофілярії, локалізовані в правому шлуночку серця собаки

Печінка незначно збільшена, в'ялої консистенції, нерівномірно забарвлена в коричневий колір, краї притуплені. На розрізі - кровонаповнена, малюнок нечіткий, зскребок незначний. Портальні лімфатичні вузли без видимих змін. Жовчний міхур середнього наповнення, жовч - червонокоричневого кольору. В одному з випадків печінка була незбільшена, пружньої консистенції, коричневого кольору, краї гострі. На розрізі кровонаповнена, малюнок чіткий, зскребок відсутній.

У процесі патолого-анатомічної оцінки селезінки спостерігали спленомегалію в двох випадках; селезінка була збільшена, кровонаповнена, в'ялої консистенції, краї дещо притуплені, виш- невого кольору з синюшним відтінком. На розрізі малюнок згладжений, зскребок відсутній. Виявляли також селезінку без видимих патологоанатомічних змін: не збільшена, пружньої консистенції, краї гострі, вишневого кольору з синюшним відтінком. На розрізі малюнок чіткий, зіскоб відсутній. В інших випадках видимих патолого-анатомічних змін не встановлено.

У нирках виявляли зміни, характерні для нефрозонефриту: нирки збільшені, бобоподібної форми, в'ялої консистенції, нерівномірно забарвлені в червоно-коричневий колір, вкриті екхімозами. Капсула знімалась важко. На розрізі межі коркового та мозкового шарів згладжені. 
ВЕТЕРИНАРНА МЕДИЦИНА

Частота виявлення патолого-анатомічних змін у собак, заражених Dirofilaria immitis, $N=5$

\begin{tabular}{|l|c|c|}
\hline \multicolumn{1}{|c|}{ Патолого-анатомічні зміни } & \multicolumn{2}{c|}{ Частота виявлення змін } \\
\cline { 2 - 3 } & випадків & $\%$ \\
\hline Кахексія & 4 & 80 \\
\hline Анемія видимих слизових оболонок & 5 & 100 \\
\hline Венозна гіперемія легень & 5 & 100 \\
\hline Набряк легень & 5 & 100 \\
\hline Гіпертрофія серця & 3 & 60 \\
\hline Гостре розширення правої половини серця & 5 & 100 \\
\hline Розрив серцевої стінки & 1 & 20 \\
\hline Гемоперикардіум & 1 & 20 \\
\hline Білковий гепатоз & 4 & 80 \\
\hline Нефрозонефрит & 3 & 60 \\
\hline Спленомегалія & 2 & 40 \\
\hline Гідроторакс & 3 & 60 \\
\hline Гемоторакс & 1 & 20 \\
\hline Асцит & 4 & 80 \\
\hline Гемоперитонеум & 1 & 20 \\
\hline Гастроентероколіт (катаральний, катарально-геморагічний) & 4 & 80 \\
\hline Катаральний цистит & 5 & 100 \\
\hline Гематурія & 4 & 80 \\
\hline Лімфаденіт (середостінних, бронхіальних та мезентеріаль- & 4 & 80 \\
\hline них лімфовузів) & 4 & 80 \\
\hline Явища геморагічного діатезу & 4 & 40 \\
\hline Наявність паразитів у легенях і легеневих судинах & 2 & 60 \\
\hline Наявність паразитів у правому шлуночку серця & 3 & \\
\hline
\end{tabular}

Сечовий міхур зменшений в об'ємі, вміст незначна кількість рідини червоного кольору 3 домішками крові (гематурія), стінка потовщена, набрякла. Серозна оболонка сірого кольору. Слизова оболонка червоного кольору, вкрита слизом і плямистими крововиливами (гострий катаральний цистит).

У більшості випадків (80 \%) конфігурація шлунка не змінена, вміст - слиз або незгорнута кров червоно-вишневого кольору 3 домішками слизу. Слизова оболонка - вишневого кольору, зібрана в складки.

Підшлункова залоза не збільшена, світлорожевого кольору, малюнок на розрізі чіткий.

Тонкий відділ кишечника порожній. Серозна оболонка червоного кольору, слизова оболонка тонкого відділу кишечника вогнищево забарвлена: виявлені ділянки вишневого та червоного кольорів, вкрита крапковими й смугастими крововиливами, вміст - слиз або кров вишневого кольору з домішками в'язкого слизу.

Слизова оболонка товстого відділу кишечника - червоного кольору, вкрита крапковими та смугастими крововиливами, вміст - слиз або кров вишневого кольору з домішками слизу.
Брижові (мезентеріальні) лімфатичні вузли збільшені, червоного кольору, капсула напружена, фолікули різко виступають.

Таким чином нами проведена загальна патолого-анатомічна оцінка п'яти випадків дирофіляріозу собак, спричиненого D. immitis. Патологоанатомічно в $100 \%$ випадків спостерігали анемію видимих слизових оболонок, венозну гіперемію, набряк легень і катаральний цистит, у 80 \% випадків - кахексію, білковий гепатоз, асцит, катарально-геморагічний чи катаральний гастроентероколіт, гематурію, лімфаденіт середостінних, бронхіальних, мезентеріальних лімфовузлів та явища геморагічного діатезу. Варіабельними патологоанатомічними ознаками були: в $60 \%$ випадків гіпертрофія серця, нефрозонефрит, гідроторакс, у $40 \%$ випадків - спленомегалія, в $20 \%$ випадків розрив серцевої стінки, гемоперикардіум, гемоторакс, гемоперитонеум.

\section{Висновки:}

1. Нами виявлені в Полтавській області випадки дирофіляріозу собак, спричиненого D. immitis.

2. Клінічно захворювання характеризувалося загальним виснаженням, слабкістю, пригнічен- 
ням, підвищуваною втомлюваністю тварин, блювотою й відмовою від корму, судомами, підвищенням температури тіла, ознаками патології дихальної та серцево-судинної систем.

3. Постійними патолого-анатомічними ознаками на розтині собак були кахексія, анемія слизових оболонок, білковий гепатоз, нефрозонефрит, гідроторакс, асцит, катаральний цистит, гематурія, зміни в серці та легенях, які є наслідком перебування

\section{БІБЛІОГРАФІЯ}

1. Артамонова А. А., Бережная В. Г. Локализация дирофилярий у человека в Ростовской области // Тез. докл. Международной научн. конф. «Актуальные проблемы медицинской и ветеринарной паразитологии». - Витебск, 1993. - С. 48. 2. Дахно І. С., Немешкало Ю. П., Дахно Г. П. [та ін.] Дирофиляриоз собак у північно-східній частині України // 3б. матеріалів III Міжнародної наук.практ. конф. / 8-9 жовтня 1998 р., м. Київ/ «Проблеми ветеринарного обслуговування дрібних домашніх тварин». - К., 1998. - С. 97-99.

3. Зон Г. А. Патологічна анатомія паразитарних хвороб тварин. - Суми: Джерело, 2005. - С. 179. 4. Карвовський О., Макаревич О., Тростянецька Ю. [ma ін.] Дірофіляріоз собак у Криму // Ветеринарна медицина України. - 1997. - №5. - С. 26.

5. Мазуркевич А. Й., Величко С. В., Василик Н. С. [ma iн.] Дирофілярюз собак у Київському perioнi: клінічна картина // Ветеринарна медицина України. - К., 2001. - С. 18-19.

6. Поживіл А. І., Мімишин В. Т., Галат В.Ф. Випадки захворювання собак на дірофіляріоз в Україні // 3б. матеріалів III Міжнародної наук.практ. конф. / 8-9 жовтня 1998 р., м. Київ / «Проблеми ветеринарного обслуговування дрібних домашніх тварин». - К., 1998. - С. 114-116.

7. Поживіл А. І., Горжеєв В. М. Дірофіляріоз статевозрілих паразитів у цих органах. Слід зазначити, що крім патогномонічних змін виявлені також катарально-геморагічне запалення у шлунково-кишковому тракті та явища геморагічного діатезу, що є неспецифічними для даного захворювання. Доцільно продовжувати подальшу роботу щодо визначення діагностичної цінності знайдених неспецифічних для захворювання змін.

собак // Ветеринарна медицина України. - 1999. - №3. - С. 38-40.

8. Потоцький М. К., Омельяненко М. М. Дірофіляріози // Ветеринарна медицина України. 2011. - №4. - С. 23-25.

9. Степанов A. B. Гельминтозы сельскохозяйственных животных в тропических странах. - М.: Типография ВАСХНИЛ, 1982. - 107 с.

10. Ястреб В.Б. Особенности патогенеза при дирофиляриозах собак, вызываемых Dirofilaria immitis и D. repens / В. Б. Ястреб // ВИГИС. Материалы докл. научн. конф. «Теория и практика борьбы с паразитарными болезнями» / ВИГИС, Москва, 2009. - С. 448-452.

11. Bredal W. P., Gjerde B., Eberhard M.L. [et al.] Adult Dirofllaria repens in a subcutaneous granuloma on the chest of a dog // J. of Small Anim. Practice. - 1998. - V. 39. - № 12. - P. 595-597.

12. Kokan A. A., Zaubach H. E. Dirofilaria immitis and Dipetalonema recondidum infections in Oklachoma dogs // JAVMA. - 1976. - №168. - P. 419-420.

13. Nelson Y. S., Heisch R. B., Furlong M. Studies in filariasis in East Africa. Filarial infections in man, animals and mosquitoes // Trans. Roi. Soc. trop. Med. Hyd. - 1962. - №56. - P. 203-217.

14. Swist $R$. A. Heatworm remonal from a limb of a dog // JAVMA. - 1980. - №177. - P. 351. 